\title{
Transnational partnerships' strategies in global fisheries governance
}

\author{
Matilda Tove Petersson ${ }^{1}$ (D)
}

Published online: 24 May 2019

(c) The Author(s) 2019

\begin{abstract}
s
This paper explores the role of transnational partnerships within a transboundary policy problem, namely illegal, unregulated, and unreported (IUU) fishing. It focuses on an understudied aspect in the partnership literature, namely 'how and why do partnerships engage in advocacy'? The article theorizes and empirically explores the variation in strategies used by transnational partnerships to shape IUU policy development and implementation, drawing on theories from comparative politics and international relations. The paper finds that transnational partnerships often combine inside strategies with service provision, but that they rarely use outside strategies, and analyzes this variation in strategies by looking at changes in issues complexity, institutional complexity, and salience for state concerning IUU fishing policy. The paper ends by discussing the implication of these findings in relation to the previous literature on interest groups in comparative politics and on international non-governmental organizations and transnational partnerships in international relations.
\end{abstract}

Keywords Transnational partnerships · Inside and outside strategies · Transboundary policy $\cdot$ Complexity $\cdot$ Salience $\cdot$ Advocacy

\section{Introduction}

The architecture of global governance is increasingly described as complex, with international organizations and international regimes at multiple levels, with partially overlapping mandates, and an increasing number of political actors operating at the global level (e.g., Zelli 2011; Ostrom 2010; Abbott 2014). Indeed, non-state actors like international non-governmental organizations (INGOs), business associations, corporations, and private research organizations are increasingly active in global environmental governance (Raustiala 1997; Risse 2012). For several decades,

Matilda Tove Petersson

matilda.petersson@su.se

1 Stockholm Resilience Centre, Stockholm University, Kräftriket 2B, 11419 Stockholm, Sweden 
these actors have been known to participate and engage in advocacy in global governance institutions (GGIs), such as the United Nations (UN) and the World Trade Organization (WTO) (Hanegraaff et al. 2016). In addition, these actors increasingly form transnational partnerships, either with other non-state actors or with state actors, to address transboundary environmental policy problems (Andonova 2010; Börzel and Risse 2005; Pattberg et al. 2012). In recent decades, the international community has also explicitly promoted the creation of partnerships between public actors, the private sector, and civil society, for example as a strategy for mobilizing and sharing resources, expertise, and capacity to implement the Sustainable Development Goals (SDGs).

Regardless of whether this trend is driven by private authority or by states and intergovernmental organizations (IGOs) themselves, the emergence of transnational partnerships has implications for GGIs operating in multiple policy areas and for the study of international regime effectiveness. The role of transnational partnerships has drawn considerable attention from international relations (IR) scholars (Arts 2002; Abbott 2014; Kalfagianni and Pattberg 2013; Pattberg et al. 2012; Pattberg and Widerberg 2016). In spite of this, there is still little scholarly agreement about the linkages between transnational partnerships and international regime effectiveness. Some scholars view transnational partnerships as an integral feature of a polycentric governance system and propose that partnerships can complement public GGIs and fill gaps in policy development and implementation needed to solve transboundary environmental problems (Ostrom 2010; Galaz et al. 2012). Others are more skeptical of the potential of partnerships to fill gaps unaddressed by public GGIs, since most partnerships emerge in areas that are already densely populated by international environmental agreements rather than in areas where public GGIs fall short (Pattberg et al. 2012). To study these potential linkages, scholars have studied the functions that transnational partnerships perform, and discussed the implications of these for the effectiveness of global environmental governance (see Schäferhoff et al. 2009 for an overview). These studies mainly focus on service provision functions, i.e., proposing that partnerships can shape effectiveness by assisting states in monitoring, policy implementation and capacity building (e.g., Pattberg et al. 2012; Marchetti 2017), or by creating private voluntary standards that other actors begin to follow (e.g., Abbott 2014; Auld et al. 2015). While most previous studies also recognize that partnerships can engage in advocacy, through activities like campaigning, agenda-setting, and lobbying (e.g., Pattberg et al. 2012; Marchetti 2017), relatively little attention has been dedicated to understanding how and why partnerships engage in these activities to shape development and implementation of global policy goals.

The main argument of this paper is that the strategies transnational partnerships use to engage in advocacy deserve more scholarly attention, as this has implications for the ability of partnerships to shape international regime effectiveness. I argue that partnerships operate as strategic actors that can both provide services to states and engage in advocacy to pursue their own interests. The variation in strategies that partnerships use to shape policy development and implementation is therefore important to consider given that these partnerships are formed by non-state actors for strategic reasons, e.g., to get faster results, pool resources, gain visibility, or for reputational benefits (e.g., 
Marchetti 2017; Auld et al. 2015), and that they are created by actors that are expected to engage in advocacy through their individual organizations.

This paper therefore focuses on the variation in strategies used by transnational partnerships in the context of a pressing but understudied transboundary policy problem, namely illegal, unregulated, and unreported (IUU) fishing. IUU fishing undermines fisheries management and can cause declining stock abundances of commercially valuable fish stocks, render significant economic losses, and have negative effects on food security in coastal communities (Agnew et al. 2009). Ending IUU fishing has been formulated as a specific policy goal under SDG14. It is a complex and transboundary policy problem that occurs across vast areas of the global ocean, both within areas of national jurisdiction and in the high seas [managed by Regional Fisheries Management Organizations (RFMOs)], by fishing operations that are highly mobile, and capable of changing vessel name, hiding behind shell companies, and taking advantage of flags of convenience (Österblom 2014). IUU fishing thus represents an excellent case for studying the role of transnational partnerships in relation to a complex and transboundary policy problem. By focusing on an understudied empirical context, this paper complements and adds new insights to existing studies of transnational partnerships in IR that predominantly focus on global climate governance (Bulkeley et al. 2014; Abbott 2014) or sustainable development more broadly (Andonova 2010; Pattberg et al. 2012; Pattberg and Widerberg 2016). In addition, by studying transnational partnerships that operate at the global level, this paper also contributes to the literature on interest groups in comparative politics where transnational advocacy and the role of this new type of collaborative actor remain understudied.

In order to understand the variation in partnership strategies, I constructed an analytical framework, combining insights from the IR literature on partnership functions (see Schäferhoff et al. 2009 for an overview) with insights on inside and outside strategies from the studies on interest groups in comparative politics (see Dür and de Bièvre 2007 for an overview) and on INGOs in IR (see Risse 2012 for an overview). Following the introductory article to this special issue (Dellmuth and Bloodgood 2019), I use the concept of political opportunity structures to consider how changes in the policy environment, in terms of issue complexity, institutional complexity, and salience shape partnership strategies.

In the next section, I present the analytical framework for studying the variation in strategies used by transnational partnerships to shape development and implementation of IUU fishing policy. Next, I present the research design and the empirical analysis before concluding by discussing the implications of the findings in relation to the literature on interest groups in comparative politics, as well as the literature on INGOs and partnerships in IR.

\section{Theoretical framework}

In the following section, I conceptualize transnational partnerships and their strategies and theorize regarding the factors that shape these strategies within the context of an increasingly complex and polycentric global governance architecture. 
Even though there is no broadly agreed definition of transnational partnerships, most scholars agree that they are (1) transnational in scope, i.e., operating across national borders, (2) multi-actor, i.e., formed by several actors and including nonstate actors, (3) pursue public policy goals and (4) can be both formal and informal arrangements (cf., Arts 2002; Andonova 2010; Bulkeley et al. 2014; Abbott 2014; Pattberg and Widerberg 2016; Schäferhoff et al. 2009).

Moreover, transnational partnerships can be divided into two overarching types: private partnerships and public-private partnerships (PPPs). Private partnerships are formed by different non-state actors. So far, the literature has mostly studied INGO-business partnerships. INGOs are believed to enter such partnerships in order to achieve faster results and achieve environmental goals, while businesses are believed to partner with INGOs for reputational benefits and new business opportunities (Arts 2002; Auld et al. 2015). According to the IR literature, non-state actors may also establish more informal advocacy coalitions with likeminded actors in order to push for policy development in GGIs, through either INGO-INGO (Betsill and Corell 2008; Klüver 2011) or INGO-business coalitions (Orach et al. 2017). The literature on private partnerships has mainly focused on the implications of increasing private authority in global governance (Abbott 2014; Green 2013), and whether private voluntary standards can enhance international regime effectiveness through case studies on certification schemes in fisheries, forestry, coffee, and soy production (Auld et al. 2015; Gulbrandsen 2009; Kalfagianni and Pattberg 2013).

PPPs refer to partnerships created by non-state actors and public actors (IGOs, states, and governmental agencies) and are often, but not always, led by a public actor (Pattberg et al. 2012). PPPs are generally considered a type of transnational relation (cf., Keohane and Nye 1971), whereby different actors join together to pursue a common goal by pooling resources, skills, and expertise, in the hope of achieving win-win solutions and shared benefits (Marchetti 2017; Schäferhoff et al. 2009). Previous studies have mainly focused on the linkages between partnerships and international regime effectiveness, by considering factors that may be important for effectiveness, such as membership composition and partnerships functions. The latter includes service provision functions like information provision, capacity building, and monitoring, but also functions related to advocacy like campaigning, lobbying, and agenda-setting (Pattberg et al. 2012; Schäferhoff et al. 2009). The literature, however, generally assumes that PPPs mainly engage in service-providing functions and thereby assist states by contributing to policy implementation (cf., Marchetti 2017).

Taken together, the literature on transnational partnerships recognizes that partnerships serve multiple functions in global governance (Pattberg et al. 2012; Schäferhoff et al. 2009), yet little attention has been dedicated to understanding how and why transnational partnerships engage in advocacy. To fill this gap, I conceptualize transnational partnerships as organizations that can provide services to states and engage in advocacy, i.e., by trying to shape policy-making in line with their interests or concerns, through direct and indirect interaction with policy-makers (Beyers et al. 2008). Moreover, I construct an analytical framework to study partnership strategies, drawing on three main aspects from previous studies of interest groups in comparative politics and INGOs in IR (e.g., Beyers 2004; Dür and Mateo 2013; Hanegraaff 
et al. 2016; Dellmuth and Tallberg 2017). First, advocacy is understood not only as a way to influence policy processes, but also as a means for groups to pursue organizational goals, such as increasing visibility, information exchange and gathering, and networking (Dellmuth and Tallberg 2017; Hanegraaff et al. 2016). Second, partnerships can combine inside and outside strategies with service provision and often cooperate with GGIs to implement global policy goals (Avant 2004; Murdie and Davis 2012; Raustiala 1997). Thirdly, the tactics used by partnerships can be categorized into inside and outside strategies. Inside strategies refer to activities that are used to influence policy processes by directly engaging with policy-makers, such as offering policy expertise or information, or by presenting the perspectives and needs of one's members or constituency. Outside strategies are activities aimed at influencing policy-making by putting pressure on policy-makers by mobilizing public opinion, such as using the media, campaigning approaches, and naming and shaming (Hanegraaff et al. 2016; Dellmuth and Tallberg 2017). Finally, I add service provision as a third category of strategies, referring to information production, policy implementation, and capacity building activities, drawing on the literature on partnerships functions (Pattberg et al. 2012; Schäferhoff et al. 2009).

\section{Political opportunity structures shaping transnational partnership strategies}

In line with Dellmuth and Bloodgood (2019), I argue that political opportunity structures at both national and global levels are important for understanding transnational partnerships' strategies, with implications for partnership effects on policy development and implementation (see also, Tarrow 2005; Skodvin and Andresen 2008; Hadden and Jasny 2017).

I focus on two changes in the policy environment that are believed to be important for the strategies used by advocacy groups: complexity (Junk 2016; Klüver 2011) and salience (Mahoney 2007).

Issue complexity refers to the nature of the policy problem and is considered high when the problem is difficult to analyze, understand, and solve, and when addressing the problem requires extensive technical expertise. Policy-makers are expected to lack sufficient information and technical expertise to solve highly complex policy problems and may therefore invite advocacy groups to provide information and services, in exchange for access (Klüver 2011; Tallberg et al. 2018). Advocacy groups are less likely to use outside strategies in relation to highly complex or technical issues, since complex issues can be difficult to communicate and mobilize public support around (Junk 2016). Instead, they are more likely to turn to inside strategies when dealing with complex issues, and to utilize opportunities provided by policy-makers.

Institutional complexity refers to changes in the institutional landscape and is associated with institutional fragmentation, an increased number of GGIs addressing the issue, and an increase in the number of public and non-state actors operating in the policy area (Keohane and Victor 2011). Greater institutional complexity indicates greater overlap across relevant GGIs, and increases the opportunities for advocacy groups to pursue advocacy, since there are a greater number of policy domains 
and more opportunities for collaboration and coalition-building with other involved actors that share similar interests (Hadden 2015; Allan and Hadden 2017).

The salience to states is related to the importance of a given policy issue to the state. Policy-makers are expected to dedicate more attention to issues that are salient to them, and less likely to consider the concerns of advocacy groups (Mahoney 2007; Klüver 2011), which may limit the opportunities for groups to pursue advocacy. At the same time, highly salient issues are expected to receive considerable attention by advocacy groups operating on multiple sides of the issue. Less salient issues are instead expected to receive little attention from states, which opens up more strategic options for advocacy groups to fill gaps in state policy and market activity (Skjelsbaek 1971; Raustiala 1997).

In the analysis section of this paper, I will categorize partnership strategies according to inside, outside, and service provision strategies. Thereafter, I will use the case of IUU fishing to analyze the variation in strategies used by transnational partnerships by looking at changes in issue complexity, institutional complexity, and salience for states. I will consider a time period of just over two decades, starting from the late 1990s, when IUU fishing was first identified as a policy problem, until today (2018).

\section{Research design}

This paper focuses on the case of IUU fishing. More specifically, illegal fishing refers to activities carried out in direct contravention to existing national or international laws. Unreported fishing refers to catch which is either not reported or misreported to the relevant national authority or RFMO. Finally, unregulated fishing refers to activities that are carried out on 'unregulated' fish stocks without established catch limits, or to fishing on regulated stock with established catch limits, but under a flag of a country that is not a party to the regulating RFMO defining such catch limits (FAO 2002). Over the past two decades, an international legal framework to combat IUU fishing has been negotiated under the auspices of the Food and Agriculture Organization of the United Nations (FAO). First, in 2001, the voluntary International Plan of Action to Prevent, Deter, and Eliminate Illegal, Unreported and Unregulated Fishing (IPOA-IUU) was adopted. Second, in 2009, the Port State Measures Agreement (PSMA), i.e., the first binding measure, was adopted (which entered into force in 2016). The implementation of global IUU policy thus occurs through the enactment of the IPOA-IUU and the PSMA at national level (the voluntary IPOA-IUU also contains provisions to be implemented by RFMOs).

The broader normative context within which transnational partnerships addressing IUU fishing policy operate has also developed considerably over the past two decades. Arguably, one of the most important issues has been the development of an Ecosystem Approach to Fisheries (EAF) which is widely recognized and promoted by policy-makers, researchers, and INGOs alike. The EAF was developed within the FAO in the early 2000s and suggests a holistic approach for achieving sustainable fisheries management, through democratic, transparent, and participatory policy processes (see Bianchi 2008 for an overview). The increasing attention 
from non-state actors on IUU fishing policy and global fisheries policy more broadly should thus be understood within this enabling normative context, whereby participation by a diverse set of stakeholders has been promoted at both national and global levels. Beyond the development of the EAF, it is also relevant to consider recent developments in international environmental law, and debates related to transnational environmental crimes, such as illegal logging and wildlife trade (see Stoett 2018 for an overview). The increasing use of legal instruments to combat environmental degradation has also been associated with a growing presence from INGOs at the global level and their activities to raise awareness for these issues (Michalowski and Kramer 2014). IUU fishing policy thus represents a policy area within which we can expect that INGOs and other types of non-state actors will have formed transnational partnerships to address this issue from a transnational environmental crime perspective.

This paper has identified a unique data set of 14 transnational partnerships that are active in IUU fishing policy. These partnerships were identified through a systematic review of case study literature, lists of participants in RFMO meetings, voluntary commitments submitted to the 2017 UN Ocean Conference, and Web sites of partnership organizations. Three inclusion criteria were used to distinguish transnational partnerships, drawing on the conceptualization of transnational partnerships as outlined above (cf., Arts 2002; Andonova 2010; Bulkeley et al. 2014; Abbott 2014; Pattberg and Widerberg 2016; Schäferhoff el al. 2009). These criteria include: being transnational in scope, having a multi-actor structure and including non-state actors, and pursuing a common goal of combating IUU fishing. Finally, I decided to focus only on 'formalized' partnerships, namely those with an official Web site, their own staff, a secretariat, an international advisory board or established working groups. The decision was taken for practical reasons and based on information availability.

Each of the 14 identified partnerships was contacted via email and asked to recommend the most suitable person within their organization to contact for an interview concerning IUU fishing. Semi-structured interviews were carried out with representatives from $12^{1}$ of the 14 identified partnerships. The remaining two partnerships were excluded from the analysis, as the information available from Web sites was insufficient. The interviews were carried out between March and May 2018, via Skype, for about 45-60 min each, and were all recorded and transcribed. ${ }^{2}$ Questions were asked about organizational characteristics, tactics and strategies used to shape development and implementation of IUU fishing policy, and changes over time (from the late 1990s until 2018) in the policy area of IUU fishing. Additional empirical material was also collected from the Web sites of the interviewed partnerships, including their year of establishment, funding sources, and publications.

\footnotetext{
1 Two interviews were carried out with one partnership, as the organization recommended two people that together would be able to speak about the organization's IUU work over time.

2 One interviewee did not wish to be recorded and, as such, notes were taken during this interview.
} 


\section{Analysis}

In this section, I describe the data set by presenting some characteristics of the 12 transnational partnerships analyzed in this paper (see Table 1). Six of the 12 partnerships included in this study are private partnerships (four emerged as partnerships between INGOs and corporations, one as a partnership between INGOs, and one as a partnership between corporations). These private partnerships are primarily funded by philanthropic foundations, or by annual fees or contributions from their corporation and/or INGO members/participants, but also receive additional funding from philanthropic foundations and voluntary contributions. The remaining six partnerships in this study are PPPs. Most of these partnerships are led by public actors (IGOs or state sub-agencies) and include non-state actors as implementing partners, except for the Fisheries Transparency Initiative (FiTI), which is led by a multi-stakeholder international board, and TRAFFIC, which is governed by an international board of trustees. TRAFFIC was included, even though it in some ways can be considered an INGO, because of its unique history. It was created in 1978 as a partnership between the International Union for Conservation of Nature (IUCN) (which includes states, government agencies, and (I)NGOs as members) and the INGO, the World Wildlife Fund (WWF). Most PPPs are funded by governments, often via development aid. Some PPPs also receive additional funds from IGOs, philanthropic foundations, and INGOs and some, like Fish-i-Africa (FiA), is entirely funded by philanthropic foundations.

\section{Variation in strategies of transnational partnerships}

In the following section, I present the variation and frequency of inside, outside, and service provision strategies used by transnational partnerships to shape IUU fishing policy (see Table 2).

Three trends are particularly noticeable. First, transnational partnerships tend to rely on inside strategies. For example, partnerships frequently participate and meet directly with policy-makers in multiple GGIs [e.g., FAO, RFMOs, International Labor Organization (ILO), United Nations Office for Drug and Crime (UNODC), Convention on International Trade in Endangered Species of Wild Fauna and Flora (CITES), International Maritime Organization (IMO) and Regional Fishery Bodies (RFBs)]. At GGI meetings, partnerships provide information, e.g., by submitting policy statements and holding side events. Taken together, the interviews show that partnerships participate in GGIs to pursue advocacy and push for policy development and/or to show visibility, to network, and to gather and exchange information, corroborating previous INGOs literature that advocacy can be understood in terms of pursuing organizational goals (cf., Dellmuth and Tallberg 2017; Hanegraaff et al. 2016). Some partnerships use inside strategies at the national level and, for example, 'regularly meet with the ministry of agriculture, the ministry of labor, the department of fisheries' (Interview 11). For some partnerships, interactions with policymakers or government officials at the national level are motivated by advocacy and pushing for policy development (Interview 12), while for others, such interactions 


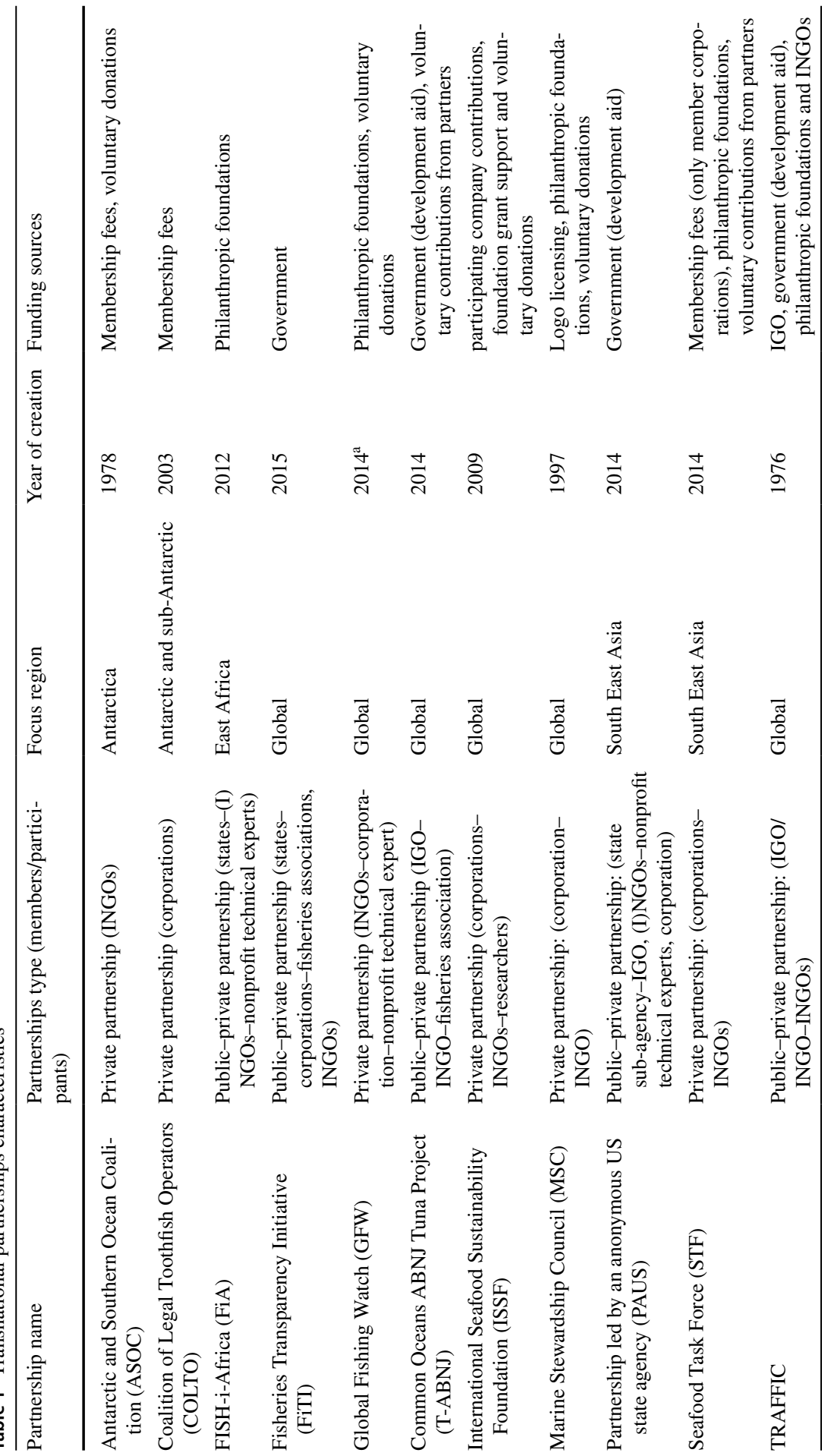

站。 


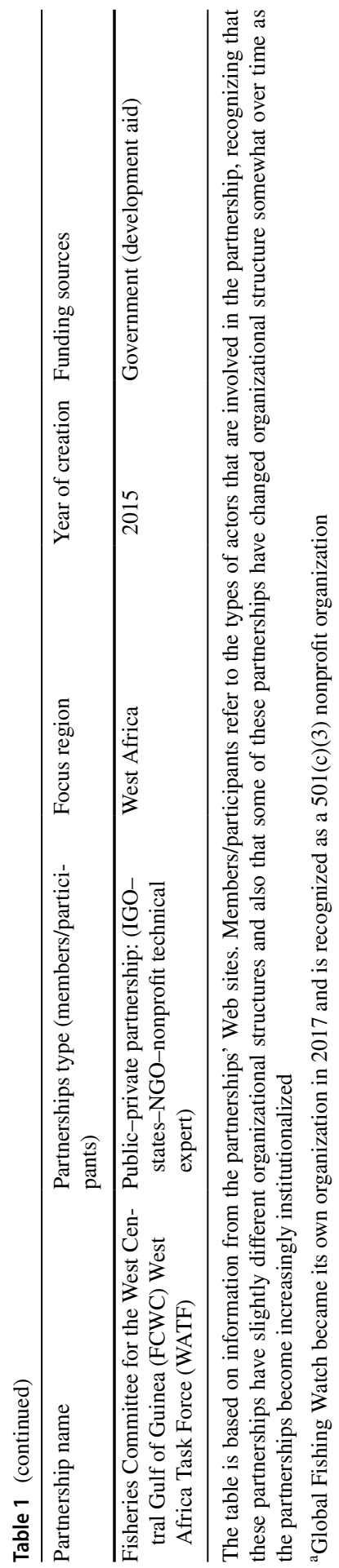




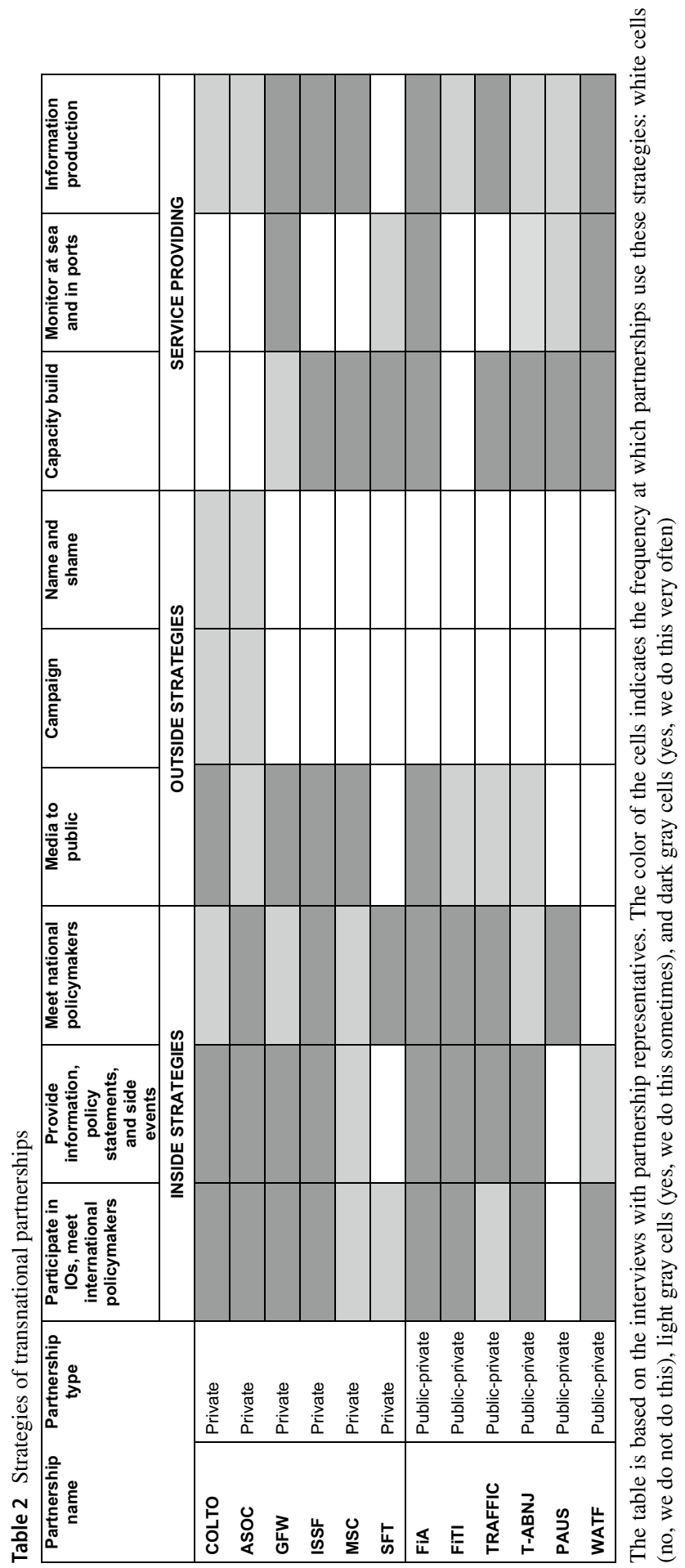

s. 
are part of regular meetings with the involved states or governmental sub-agencies of the partnerships (Interview 13). Taken together, the interviews suggest that transnational partnerships tend to rely on inside strategies at both global and national levels because they are able to. Transnational partnerships appear to have access to multiple GGI meetings, corroborating previous studies that the opening up of institutional access to GGIs has led to an increased participation by advocacy groups (cf., Tallberg et al. 2013) and that these groups provide information and services of interest to policy-makers, at such meetings, in exchange for access (Tallberg et al. 2018). Similarly, at the national level, private partnerships seem to have access to policy-makers as a function of the services they provide, while PPPs have access to policy-makers and government officials that are part of the partnerships.

Second, partnerships rely on service-providing strategies (see Table 2). For example, several partnerships use satellite vessel tracking data to monitor and analyze fishing activities and are engaged in capacity building, working with port inspectors, customs personnel, and government staff, focusing on developing monitoring, control and surveillance (MCS) systems and on implementing, e.g., the PSMA, RFMO provisions, and CITES regulations. Many partnerships also produce policy-relevant information, focusing on various aspects of IUU fishing, such as transshipment, analyzing vessel tracking data, evaluating MCS systems, and RFMO measures. Several partnerships combine service provision with working directly with governments using inside strategies. For example, one partnership representative said 'one of the main ideas of the partnership is to be a bridge between technology and what you probably would call political influence. Being able to take information and make it understandable and give it to the countries that actually have the mandate and the authority to take action' (Interview 2).

Third, partnerships rarely use outside strategies. While nearly all partnerships use the media to communicate their work around IUU fishing, this it rarely done as part of a campaigning approach to explicitly mobilize public support, but rather to inform the public and other relevant actors of their activities. One respondent perceived naming and shaming tactics as 'totally unproductive' (Interview 11), another emphasized that they 'don't have that same style of advocacy [as other INGOs]' (Interview 10), and a third said that they need to remain neutral (Interview 4). According to one respondent, they 'sometimes cooperate with other organizations, let them do the naming and shaming' (Interview 2). According to representatives of the two partnerships that sometimes use tactics like naming and shaming and campaigning, these outside strategies were used more frequently in the past, when IUU fishing was a more extensive problem in the region they both operated in, when the issues were a new policy problem and before an international legal framework had been developed. During the late 1990s and early 2000s, these partnerships frequently used outside strategies to raise awareness and push for action by calling out flag states enabling IUU fishing to happen and IUU operators that were engaged in IUU fishing activities. According to one of these partnerships, their focus and strategies have changed since then: 'on a daily basis, we're not doing the more dramatic stuff, like finding poachers or pirate vessels. The focus has shifted towards creating a strong compliance and enforcement system' (Interview 7). 


\section{Changes in political opportunity structures: complexity and salience}

In the following section, I analyze the variation in transnational partnerships' strategies by looking at changes in issue and institutional complexity, and salience for states. The analysis of changes in the policy environment is based on the respondents' perceptions of the changes in IUU fishing policy from the late 1990s until today.

The interviews suggest that IUU fishing has increased in issue complexity since the late 1990s when it was first identified as a fisheries management problem in the Southern Ocean. Today, IUU fishing is increasingly recognized as a complex problem with multiple causes and consequences. IUU fishing is no longer only about fisheries policy, but increasingly being discussed in relation to other problems in the fisheries sector like fraud, tax evasion, human trafficking, modern slavery, and labor abuse (UNODC 2011). Some partnerships have expanded their focus, to increasingly view IUU fishing as a socio-economic problem (Interviews 12, 13). Other partnerships have emerged specifically to address IUU fishing from the perspective on fisheries crime (Interviews 1, 2) or related to labor abuse (Interviews 11,13 ) in the fishing sector. For example, one partnership representative said 'IUU fishing was created by the FAO to describe a problem in fisheries management. But it isn't really covering what this is really about. I like to call it illegal fishing and fisheries associated crime' (Interview 2). The broadening of IUU fishing as a more complex policy problem thus seems to shape the way partnerships address and view the problem.

The analysis shows that transnational partnerships combine inside strategies and service provision (Table 2) and thus seem to corroborate previous studies that when dealing with complex issues, transnational partnerships get access to policy-makers through an exchange of information and service provision (Tallberg et al. 2018; Klüver 2011). For example, one partnership representative described how they currently work to combat fisheries crime by providing services to states in relation to law enforcement: "we have our own investigators [to] assist the police and the fisheries department to make sure that the evidence collection is done technically correct, to build up the confidence of the decision-makers to take legal actions' (Interview 2). Another partnership representative explained that the organization first began to address IUU fishing because policy-makers lacked information about the problem and asked for their expertise: "we were asked by the department of fisheries to do a trade analysis in the late 90 s, early 2000s [...] They were aware that there were really high levels of IUU fishing, but they didn't know where the fish was going' (Interview 12). Moreover, that partnerships rarely use outside tactics such as campaigning and naming and shaming may in part be explained by the complexity of the issue, i.e., making it difficult to gather public support around (Junk 2016). According to one partnerships representative, there is a tendency to communicate the more spectacular aspects of IUU fishing: 'People like the idea of chasing pirates' as it is easy to communicate that this in general is 'bad stuff,' but the full complexity of IUU fishing is more difficult to communicate (Interview 6). 


\section{Increase in institutional complexity}

The institutional landscape addressing IUU fishing has increased considerably in complexity since the late 1990s, with an increasing number of GGIs addressing IUU fishing over time. When IUU fishing was first detected in the 1990s, it was addressed by GGIs in fisheries policy, i.e., the FAO and RFMOs. Being increasingly considered an economic problem, GGIs dealing with economic and trade policy have also started to address IUU fishing: For example, the Organisation for Economic Co-operation and Development (OCED) work on the linkages between IUU fishing, tax evasion, and fraud (see OECD 2005) and the World Trade Organization (WTO) are considering IUU fishing in their ongoing negotiations on fisheries subsidies (Schmidt 2017). More recently, the UNODC and INTERPOL started to work on transnational marine and fisheries crime, and ILO on the connections with between fisheries crime and forced labor. Table 2 shows that transnational partnerships frequently use inside strategies. For some partnerships, participating in meetings of multiple GGIs enables them to make specific asks and to address an issue from several angles, for example, asking the IMO to require fishing vessels to have IMO numbers and asking the RFMOs to enforce compulsory vessel monitoring systems (VMS) and enhance observer coverage onboard vessels to improve MCS systems (Interviews 6), or pushing for species to be listed by CITES to combat illegal wildlife trade, as well as participating in the ongoing discussions in the UNODC about transnational fisheries crime (Interview 12).

The institutional landscape has also become increasingly complex and fragmented by the emergence of private authority and use of market-based approaches in fisheries governance. This is indicated by the increasing uptake and legitimacy of fisheries certification schemes (Gulbrandsen 2009; Kalfagianni and Pattberg 2013) and the use of market-based measures to combat IUU fishing used by public actors, e.g., the 2010 EU-IUU regulations and the 2018 US Seafood Import Monitoring Program. These trends are also well reflected in the focus of several partnerships. Some partnerships have established their own private voluntary standards, such as certification schemes or standards that participating industry actors can commit to, including annual audits of those commitments (Interviews 5, 10) and are themselves part of driving the emergence of private authority and market-based approaches in fisheries governance, while others have changed their activities to include a 'bigger focus on market and consumer awareness around IUU sourced products' (Interview 12) as a response to this development. Some respondents view the emergence of other sustainability initiatives (often using private authority and market-based approaches) as important for their own initiative. For example, one respondent said 'the rise of other types of mechanisms to improve fisheries, such as fisheries improvement projects or the MSC certification system, and the resulting evolution of awareness and tools has only broadened our ability to combat IUU fishing' (Interview 10). 


\section{Increase in salience for states}

State salience for IUU fishing has generally increased since the late 1990s. This is indicated by the establishment of international, regional, and national legal frameworks. These include the IPOA, the PSMA, RFMO measures, and the recent EU and US regulations (that put pressure on export countries using market power) as well as multilateral efforts (e.g., the high seas ministerial task force established in 2005) and joint statements (e.g., the Southern African Development Community statements from 2008) to combat IUU fishing. According to two partnership representatives, the partnerships emerged because of a combination of increasing salience in some export countries resulting from the recent IUU regulations by the EU and the USA, and an increasing complexity of the issue, increasingly being related to human rights violations and labor abuse (Interviews 11, 13). Two other partnership representatives said they emerged in part because salience has increased in several developing states that historically do not have large industrial fishing fleets and instead sell fishing access rights to distant water fishing nations. One of these partnership representatives said 'in the late 90s, certainly discussing what was going on in the water was not a priority for these states,' but that today 'the value of the fishery for food security and broader national income is much better understood. [...] There's been a massive progress in the last three to 4 years, on the strengthening and enforcement of national legal frameworks' (Interview 1). The same respondent explained why the partnership was formed: 'the member states had signed various regional agreements, for example on information sharing, but they were just bits of paper. The idea of the partnership was basically to operationalize a lot of what had been politically agreed, but not implemented' (Interview 1). One of the reasons for the emergence of PPPs in developing countries may be a lack of resources to combat IUU fishing. Developing countries may thus enter partnerships with non-state actors in exchange for the provision of services like vessel tracking data and analysis of that data and capacity building to support port inspectors to enforce MCS systems needed to combat IUU fishing. The emergence of such partnerships may also in part be driven by the international development agenda, since several PPPs are funded by development aid (Table 1). One partnership representative described how they provide services to states: "we are really taking out raw data from AIS, analyzing each single position [...]. This means that if the vessel comes into country A and gets inspected and it leaves and it goes to country B, we can have all of that information in country B before the vessel arrives. If something serious is found, we can try to convince the countries to implement for example the port state measure agreement or RFMO resolutions to deny access' (Interview 2). That partnerships emerge around issues that are increasing in salience supports Skjelsbaek's (1971) argument that transnational partnerships (similar to INGOs) emerge in areas which are most relevant for states and in which public actors are most active. 


\section{Conclusions}

In this concluding section, I discuss the findings of this paper and the contributions to three bodies of literature, i.e., related to interest groups in comparative politics, INGOs in IR, and transnational partnerships in IR.

First, these findings contribute to the literature on interest groups in comparative politics, by demonstrating the value of considering service provision strategies alongside inside and outside strategies. By considering service provision, interest group scholars may be able to study the effects of interest groups in later stages of the policy process, i.e., on policy implementation, which generally have been given less attention in interest group research, as compared to effects on earlier stages of the policy process, such as decision making and policy development (cf., Hanegraaff et al. 2016; Dür and Mateo 2013; Dellmuth and Tallberg 2017). In addition, this paper focuses on a new type of actors, which so far has attracted relatively little attention within the interest group literature, even though transnational partnerships engage in advocacy, alongside other activities to pursue their goals, and notably are formed by at least one non-state actor that engages in advocacy in its own capacity. This paper thus suggests that interest groups scholars should pay more attention to the phenomena of transnational partnerships and to understanding their effects in both national and international political systems.

Second, this study contributes to the INGO literature in IR, by emphasizing the importance of political opportunity structures, such as institutional complexity, for the strategies that are made available to advocacy groups. Taken together, the findings of this paper show that the increasing institutional complexity and fragmentation related to IUU fishing policy, in terms of an increasing number of GGIs together with generous access rules have enabled transnational partnerships to participate and develop specific asks for multiple GGIs. Moreover, the emergence of private authority and the increasing use of market-based approaches seem to be in part driven by some of these partnerships, while others have responded by adapting their activities or emerged as a result of these trends. This corroborates previous studies which found that an increasingly fragmented institutional landscape provides additional venues, which increases the number of distinct political actors and networking opportunities available to such actors, thereby increasing the likelihood of new collaborative arrangements between political actors operating at global scale (Keohane and Victor 2011; Hadden 2015; Allan and Hadden 2017). Transnational partnerships are themselves part of driving this development, as a way to pursue their own interests and to get an increasing number of political actors to implement their rules. Today, private voluntary standards are increasingly viewed as multi-stakeholder GGIs (e.g., Dellmuth and Bloodgood 2019; Buchanan and Keohane 2006), probably as a result of increasing legitimacy and uptake of such private standards. The increasingly fragmented (cf., Zelli 2011) and polycentric (cf., Ostrom 2010) global governance architecture may thus have implications for the strategies and opportunities made available to INGOs to pursue advocacy, and ultimately for their effects on GGI policy processes. The INGO literature has generally attributed relatively little importance to 
the institutional context in shaping strategies, as INGOs are expected to use their transnational networks to bypass institutional obstacles (Keck and Sikkink 1998). However, this paper proposes that INGO scholars should pay more attention to the institutional context, in an ever more fragmented and polycentric global governance architecture.

Finally, the findings of this paper contribute to the existing IR literature on transnational partnerships in relation to transboundary environmental policy problems, by studying the role of transnational partnerships in a new empirical context. In contrast to previous studies on partnerships (e.g., Marchetti 2017), the paper shows that partnerships mostly use inside strategies. It also finds that partnerships both participate in multiple GGIs to make specific demands for policy development, and/or to maintain organizational goals such as visibility, information sharing and gathering, and networking (cf., Dellmuth and Tallberg 2017; Hanegraaff et al. 2016). The paper also finds that partnerships are more likely to rely on inside strategies when dealing with complex problems because they often get access to policy-makers (through an exchange of information and service provision) (Tallberg et al. 2018; Klüver 2011), and also because complex problems are difficult to communicate and mobilize public support around using outside strategies (Junk 2016). This may be true for partnerships operating in other transboundary environmental policy areas as well, given that these often are characterized by high issue complexity, increased salience for states, and an increasingly complex institutional architecture. At the same time, different transboundary environmental policy areas may still vary in scope, relative issue complexity and salience for states, as well as by the number of non-state actors and transnational partnerships operating in the policy areas. One can imagine how an increasing number of actors may not only increase collaboration between likeminded actors, but also increase competition over limited resources and over access to policy-makers at national and global level, as well as increase the number of countervailing actors, with implications for the strategies and effects of transnational partnerships. This paper also corroborates previous studies that partnerships frequently rely on service provision strategies, such as monitoring and capacity building. This suggests that transnational partnerships combine inside strategies and service provision to shape development and implementation of IUU fishing policy, and operate similarly to service INGOs (Avant 2004; Murdie and Davis 2012; Raustiala 1997). Future studies would thus benefit from considering a broader range of partnership strategies in order to understand whether and how partnerships can shape the effectiveness of international regimes. A fruitful avenue for future study would be to further unpack the potential linkages between the partnership strategies and regime effectiveness by drawing on the previous interest group literature that considers additional issue characteristics to measure lobbying success including the scope of the policy issue, presence of countervailing factors, or a focusing event (see, e.g., Mahoney 2007). Future studies focusing on the effects of transnational partnerships would also benefit from triangulating observations from both partnership representatives and relevant policy-makers in the policy area in question.

Acknowledgements This research is a product of the Nereus Program, a collaborative initiative funded by the Nippon Foundation and with partners including Stockholm University and the University of British 
Colombia. Earlier versions of this article were presented at the Global and Regional Governance seminar at Stockholm University, the 2018 special issue workshop on Interest Groups, International Organizations, and Global Problem-solving Capacity at Stockholm University, the 2018 General Conference of the European Consortium for Political Research (ECPR) in Hamburg and the 2018 Earth System Governance Conference in Utrecht. I am particularly grateful to Lisa Dellmuth, Henrik Österblom, Robert Blasiak, Elizabeth Bloodgood, and Helen Yanacopulos for providing helpful comments and suggestions.

\section{Compliance with ethical standards}

Conflict of interest There is no conflict of interest stated by the author of this article.

Open Access This article is distributed under the terms of the Creative Commons Attribution 4.0 International License (http://creativecommons.org/licenses/by/4.0/), which permits unrestricted use, distribution, and reproduction in any medium, provided you give appropriate credit to the original author(s) and the source, provide a link to the Creative Commons license, and indicate if changes were made.

\section{References}

Abbott, K.W. 2014. Strengthening the Transnational Regime Complex for Climate Change. Transnational Environmental Law 3(1): 57-88.

Agnew, D.J., J. Pearce, G. Pramod, T. Peatman, R. Watson, R. John, and T.J. Pitcher. 2009. Estimating the Worldwide Extent of Illegal Fishing. PLoS ONE 4(2): e4570.

Allan, J., and J. Hadden. 2017. Exploring the framing power of NGOs in Global Climate Politics. Environmental Politics 26(4): 600-620.

Andonova, L.B. 2010. Public-Private Partnerships for the Earth: Politics and Patterns of Hybrid Authority in the Multilateral System. Global Environmental Politics 10(2): 25-53.

Arts, B. 2002. 'Green Alliances' of Business and NGOs. New Styles of Self-Regulation or 'Dead-End Roads'? Corporate Social Responsibility and Environmental Management 9: 26-36.

Auld, G., S. Renckens, and B. Cashore. 2015. Transnational Private Governance Between the Logics of Empowerment and Control. Regulation and Governance 9(2): 108-124.

Avant, D. 2004. Conserving Nature in the State of Nature: The Politics of INGO Policy Implementation. Review of International Studies 30(3): 361-382.

Betsill, M.M., and E. Corell. 2008. NGO Diplomacy: The Influence of Nongovernmental Organizations in International Environmental Negotiations. Cambridge, MA: MIT Press.

Beyers, J. 2004. Voice and Access: Political Practices of European Interest Associations. European Union Politics 5(2): 211-240.

Beyers, J., R. Eising, and W. Maloney. 2008. Researching Interest Group Politics in Europe and Elsewhere: Much We Study, Little We Know? West European Politics 31(6): 1103-1128.

Bianchi, G. 2008. The Concept of the Ecosystem Approach to Fisheries in the FAO. In The Ecosystem Approach to Fisheries, ed. G. Bianchi, and H.R. Skjoldal, 20-38. Rome: The Food and Agriculture Organizations of the United Nations (FAO).

Börzel, T.A., and T. Risse. 2005. Public-private partnerships: Effective and legitimate tools of international governance? In Complex Sovereignty: Reconstructing Political Authority in the Twenty First Century, ed. Edgar Grande and Louis W. Pauly, 195-216. Toronto: Toronto University Press.

Buchanan, A., and R.O. Keohane. 2006. The Legitimacy of Global Governance Institutions. Ethics and International Affairs 20(4): 405-437.

Bulkeley, H., L.B. Andonova, M.M. Betsill, D. Compagnon, T. Hale, M.J. Hoffmann, P. Newell, M. Paterson, C. Roger, and S.D. VanDeveer. 2014. Making a Difference? Tracing the Effects and Effectiveness of Transnational Climate Change Governance. In Transnational Climate Change Governance, 158-177. Cambridge: Cambridge University Press.

Dellmuth, L.M., and J. Tallberg. 2017. Advocacy Strategies in Global Governance: Inside vs. Outside Lobbying. Political Studies 65(3): 705-723. https://doi.org/10.1177/0032321716684356.

Dellmuth L.M., and E. Bloodgood. 2019. Advocacy Group Effects in Global Governance: Populations, Strategies, and Political Opportunity Structures. Interest Groups and Advocacy.

Dür, A., and D. de Bièvre. 2007. The Question of Interest Group Influence. Journal of Public Policy 27(1): $1-12$. 
Dür, A., and G. Mateo. 2013. Gaining Access or Going Public? Interest Group Strategies in Five European Countries. European Journal of Political Research 52(5): 660-686.

FAO. 2002. Implementation of the International Plan of Action to Prevent, Deter and Eliminate Illegal, Unreported and Unregulated Fishing. Rome: FAO Fisheries and Aquaculture Department.

Galaz, V., B. Crona, H. Österblom, P. Olsson, and C. Folke. 2012. Polycentric Systems and Interacting Planetary Boundaries: Emerging Governance of Climate Change-Ocean Acidification-Marine Biodiversity. Ecological Economics 81: 21-32.

Green, J.F. (ed.). 2013. Rethinking Private Authority: Agents and Entrepreneurs in Global Environmental Governance. Princeton, NJ: Princeton University Press.

Gulbrandsen, L.H. 2009. The Emergence and Effectiveness of the Marine Stewardship Council. Marine Policy 33(4): 654-660.

Hadden, J. 2015. Networks in Contention: The Divisive Politics of Global Climate Change. Cambridge: Cambridge University Press.

Hadden, J., and L. Jasny. 2017. The Power of Peers: How Transnational Advocacy Networks Shape NGO Strategies on Climate Change. British Journal of Political Science 1-23.

Hanegraaff, M., J. Beyers, and I. De Bruycker. 2016. Balancing Inside and Outside Lobbying: The Political Strategies of Lobbyists at Global Diplomatic Conferences. European Journal of Political Research 55(3): $568-588$.

Junk W.M. 2016. Two logics of NGO advocacy: understanding inside and outside lobbying on EU environmental policies. Journal of European Public Policy 23(2): 236-254.

Kalfagianni, A., and P. Pattberg. 2013. Fishing in Muddy Waters: Exploring the Conditions for Effective Governance of Fisheries and Aquaculture. Marine Policy 38: 124-132.

Keck, M.E., and K. Sikkink. 1998. Activists Beyond Borders: Advocacy Networks in International Politics. Ithaca, NY: Cornell University Press.

Keohane, R.O., and J.S. Nye Jr. (eds.). 1971. Transnational Relations and World Politics. Cambridge, MA: Harvard University Press.

Keohane, R., and D. Victor. 2011. The Regime Complex for Climate Change. Perspectives on Politics 9(1): 7-23.

Klüver, H. 2011. The Contextual Nature of Lobbying: Explaining Lobbying Success in the European Union. European Union Politics 12(4): 483-506.

Mahoney, C. 2007. Lobbying Success in the United States and the European Union. Journal of Public Policy 27(1): 35-56.

Marchetti, R. (ed.). 2017. Partnerships in International Policy-Making: Civil Society and Public Institutions in European and Global Affairs. London: Palgrave Macmillan.

Michalowski, R., and R. Kramer. 2014. Transnational Environmental Crime. In Handbook of Transnational Crime and Justice, ed. P. Reichel and J. Albanese, 189-212. Thousand Oaks: SAGE Publications.

Murdie, A., and D. Davis. 2012. Looking in the Mirror: Comparing INGO Networks Across Issue Areas. Review of International Organizations 7(2): 177-202.

OECD. 2005. Why Fish Piracy Persists: The Economics of Illegal, Unreported and Unregulated Fishing. Paris: Organisation for Economic Co-operation and Development.

Orach, K., M. Schlüter, and H. Österblom. 2017. Tracing a Pathway to Success: How Competing Interest Groups Influenced the 2013 EU Common Fisheries Policy Reform. Environmental Science \& Policy 76: $90-102$

Österblom, H. 2014. Catching Up on Fisheries Crime. Conservation Biology 28(3): 877-879.

Ostrom, E. 2010. Polycentric Systems for Coping with Collective Action and Global Environmental Change. Global Environmental Change 20(4): 550-557.

Pattberg, P., F. Biermann, S. Chan, and A. Mert (eds.). 2012. Public-Private Partnerships for Sustainable Development: Emergence, Influence, and Legitimacy. Cheltenham: Edward Elgar.

Pattberg, P., and O. Widerberg. 2016. Transnational Multistakeholder Partnerships for Sustainable Development: Conditions for Success. Ambio 45(1): 42-51.

Raustiala, K. 1997. States, NGOs, and International Environmental Institutions. International Studies Quarterly 41(4): 719-740.

Risse, T. 2012. Transnational Actors and World Politics. In Handbook of International Relations. 2nd ed, ed. W. Carlsnaes, T. Risse, and B.A. Simmons, 426-452. London: Sage.

Schäferhoff, M., S. Campe, and C. Kaan. 2009. Transnational Public-Private Partnerships in International Relations: Making Sense of Concepts. Research Frameworks, and Results. International Studies Review 11: $451-474$. 
Schmidt, C.-C. 2017. Issues and Options for Disciplines on Subsidies to Illegal, Unreported and Unregulated Fishing. Geneva: International Centre for Trade and Sustainable Development (ICTSD).

Skjelsbaek, H. 1971. The Growth of International Non-Governmental Organizations in the Twentieth Century. International Organizations 25(3): 420-442.

Skodvin, T., and S. Andresen. 2008. Nonstate Influence in the International Whaling Commission, 19701990. In NGO Diplomacy: The Influence of Nongovernmental Organizations in International Environmental Negotiations, ed. M.M. Betsill and E. Corell, 119-145. Cambridge, MA: MIT Press.

Stoett, P. 2018. Transnational Environmental Crime. In The Routledge Handbook of Environmental Conflict and Peacebuilding, ed. A. Swain, 29-41. London: Routledge.

Tallberg, J., L.M. Dellmuth, A. Duit, and H. Agné. 2018. NGO Influence in International Organizations: Information, Access, and Exchange. British Journal of Political Science 48(1): 213-238.

Tallberg, J., T. Sommerer, T. Squatrito, and C. Jönsson. 2013. The Opening Up of International Organizations: Transnational Access in Global Governance. Cambridge: Cambridge University Press.

Tarrow, S. 2005. The New Transnational Activism. Cambridge: Cambridge University Press.

UNODC. 2011. Transnational Organized Crime in the Fishing Industry. Focus on: Trafficking in Persons Smuggling of Migrants Illicit Drugs Trafficking. Vienna: United Nations Office on Drugs and Crime (UNODC).

Zelli, F. 2011. The Fragmentation of the Global Climate Governance Architecture. Wiley Interdisciplinary Reviews: Climate Change 2(2): 255-270.

Publisher's Note Springer Nature remains neutral with regard to jurisdictional claims in published maps and institutional affiliations. 